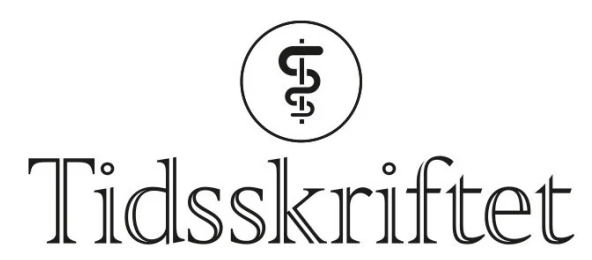

DEN NORSKE LEGEFORENING

\title{
Virale valgmøter
}

\section{MINILEDER}

\section{ARE BREAN}

Sjefredaktør

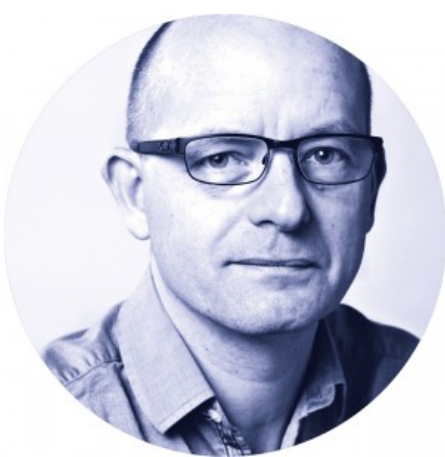

Det begynte med noen få smittede på et matmarked i Wuhan. Nå, 11 måneder senere, er over en million mennesker døde i covid-19-pandemien. Det kan være flere enn de som er døde av hiv, malaria, kolera, meslinger, influensa og dysenteri til sammen i samme periode. Likevel er dette et minimumstall - det reelle antallet døde er sannsynligvis høyere, ifølge Verdens helseorganisasjon. Og veksten i antall tilfeller fortsetter. Innen året er omme, kan covid-19 ha overtatt for tuberkulose som verdens dødeligste infeksjonssykdom i 2020.

USA er blant de aller hardest rammede landene. Med omtrent $4 \%$ av verdens befolkning har USA $20 \%$ av verdens covid-19-dødsfall så langt. Redaktørene i den amerikanske legeforeningens tidsskrift, JAMA, ser tre hovedårsaker: en «infodemi» av desinformasjon og falske nyheter om pandemien, de mange svakheter i det amerikanske helsevesenet som har hindret effektiv hjelp samt den haltende og fragmenterte responsen fra de nasjonale myndighetene. Om et par uker er det presidentvalg i USA. Den sittende presidentens utallige valgmøter over hele landet samler jevnlig flere tusen deltagere, som står tett sammen i idrettshaller og på stadioner. Det etterlater liten tvil om at analysen i JAMA treffer tragisk godt.

Publisert: 12. oktober 2020. Tidsskr Nor Legeforen. DOI: 10.4045/tidsskr.20.14.01

(C) Tidsskrift for Den norske legeforening 2023. Lastet ned fra tidsskriftet.no 26. april 2023. 